\title{
KOMITMEN ORGANISASI, AKUNTABILITAS DAN ORGANIZATION CITIZENSHIP BEHAVIOR INSTITUSI MILITER, (Studi Empiris Di Angkatan Udara Republik Indonesia)
}

\author{
Hadi Mahmudah dan Supeni A. Mapuasari \\ Universitas Islam Empat Lima dan Universitas Presiden \\ Email:hadi_mahmudah@yahoo.com dan supeni@presiden.ac.id
}

\begin{abstract}
This research evaluates the effect of organizational commitment and accountability towards organizational citizenship behavior in Military Institution in Indonesia. Data was collected by survey method in Indonesian Airforce located in Yogyakarta. One hundred questionaires gathered and analized with smart PLS. The result of this research shows that organizational commitment influences organization citizenship behaviour. In addition, accountability mediates the relationship of organizational commitment and organization citizenship behaviour. This research inspired by the phenomenon that there is little research on military area regarding accountability, either in Indonesia or in the world. Thus, this research will give a siginificant literature contribution based on the empirical data analyzes in Military Institution in Indonesia.
\end{abstract}

Keywords: organizational citizenship behavior, accountability, organization tenure, normative commitment, dan continuance commitment.

\begin{abstract}
Abstrak: Riset ini mengevaluasi efek dari komitmen organisasi dan akuntabilitas terhadap perilaku organisasi di organisasi militer di Indonesia. Survei disebarkan kepada Tentara Nasional Angkatan Udara Republik Indonesia yang berlokasi di Yogyakarta. Dari seratus kuesioner yang tersebar, tingkat pengembalian $100 \%$. Hasil penelitian menunjukkan bahwa komitmen organisasi mempengaruhi perilaku kerja. Selain itu, akuntabilitas memediasi hubungan antara komitmen organisasi dan perilaku kerja. Riset ini terinspirasi oleh fenomena sedikitnya riset serupa di dunia kemiliteran yang terkait dengan akuntabilitas, baik di Indonesia maupun di dunia. Oleh sebab itu, riset ini diharapkan dapat memberikan kontribusi literatur yang signifikan, yaitu kontribusi yang berbasiskan bukti empiris yang terjadi di Tentara Nasional Republik Indonesia.
\end{abstract}

Kata kunci: Perilaku kerja, akuntabilitas, kontrak kerja, komitmen normatif, dan komitmen berkelanjutan.

\section{PENDAHULUAN}

Akuntabilitas merupakan salah satu prinsip utama tata kelola pemerintahan yang baik (good governance) yang mengisyaratkan adanya perwujudan kewajiban seseorang atau unit organisasi untuk mempertanggungjawabkan pengelolaan dan pengendalian sumber daya dan pelaksanaan kebijakan yang dipercayakan kepadanya. Hal ini dilakukan dalam rangka pencapaian tujuan yang telah ditetapkan melalui media pertanggungjawaban secara periodik (LAN, 2010).Isu akuntabilitas diangkat mulai dari tahun 1999, yaitu 
ditandai dengan dikeluarkannya Instruksi Presiden No.7 tahun 1999 tentang pelaporan akuntabilitas. Akbar (2012) menyatakan bahwaperaturann tersebut sangat penting untuk mendukung transparansi dan akuntabilitas yang merupakan prinsip utama dari tata kelola pemerintah yang baik (good governance).

Akuntabilitas diharapkan mampu mendukung reformasi birokrasi, seperti yang diamanatkan di Undang-undang no 17 tahun 2007 tentang Rencana Pembangunan Jangka Panjang Nasional 2005-2025. Reformasi birokrasi di Indonesia dilakukan untuk membangun aparatur negara yang mendukung keberhasilan pembangunan bidang lainnya. Keberhasilan reformasi birokrasi salah satunya ditandai dengan peningkatan kinerja aparatur negara karena pembangunan aparatur negara diyakini mampu meningkatkan kinerja institusi pemerintah. Oleh sebab itu, kinerja menjadi isu sentral terkait dengan governance dan akuntabilitas. Kinerja pemerintah selalu terkait erat dengan perilaku kerja aparatur negara. Perilaku kerja dalam hal ini disebut organization citizenship behaviour.

Organization citizenship behavior (OCB) biasanya disebut perilaku kewarganegaraan adalah tindakan ekstra yang melebihi deskripsi peran karyawan. Tidakan ekstra yang dilakukan karyawan contohnya menolong rekan, berpartisipasi aktif, menggunakan waktu kerja secara efektif, tidak membolos ketika hari kerja dan lain sebagainya. Dengan kata lain karyawan tidak hanya mengerjakan tugas pokoknya (in-role) saja tetapi mengerjakan tugas ekstra yang membuat nilai lebih untuk keefektifan organisasi. Organizational citizenship behavior (selanjutnya OCB) merupakan model kegiatan yang membuat organisasi secara instrinsik dapat bekerja sama (Katz dan Khan,1966 dalam Ariani, 2011). Menurut Ariani (2011) organisasi efektif apabila individu yang masuk kedalam organisasi itu mau menunjukkan peran dengan kriteria minimal untuk mencapai kinerjanya dan mempunyai perilaku yang inovatif dan sportif dalam menjalankan fungsi organisasi.

Penelitian komitmen organisasi terhadap Organization citizenship behavior telah banyak dilakukan (Riketta dan Landerer, 2002; Ng dan Feldman, 2011). Ng dan Feldman (2011) menguji komitmen organisasi terhadap perilaku dengan kontrak kerja (organizational tenure) sebagai variabel pemoderasi. Hasilnya, kontrak kerjamemoderasi hubungan komitmen organisasi dan organization citizenship behavior.Menurut Baretto dan Ellemer (2000) dalam Riketta dan Landerrer (2002) perilaku kerja (OCB) bergantung pada dua faktor yaitu identifikasi anggota group dan akuntabilitas dengan yang lainya.

Riketta dan Landererer (2002) juga mengungkapkan bahwa komitmen organisasi dapat digunakan untuk mengidentifikasi kinerja karyawan. Penelitian ini memperluas penelitian Riketta dan landerrer (2002) yang meneliti pengaruh komitmen organisasi terhadap perilaku kerja dengan akuntabilitas sebagai variabel pemoderasi. Hasil penelitian Riketta dan Lenderrer (2002) justru menyatakan bahwaakuntabilitas bukan sebagai variabel pemoderasi, tetapi sebagai variabel yang independen. Akuntabilitas sebagai variabel pemoderasi dalam penelitian Riketta dan landerer (2002) tidak terdukung. Terdapat kemungkinan akuntabilitas bukan sebagai variabel pemoderasi tetapi sebagai variabel intervening. Ppenelitian ini menguji kebenaran dugaan bahwa akuntabilitas memediasi hubungan antara komitmen organisasi dan organization citizenship behavior.

Penelitian Riketa dan Landerer (2002)hanya menguji akuntabilitas eksternal. Penelitian ini menguji baik akuntabilitas internal maupun akuntabilitas eksternal.Peneliti berargumen bahwa didalam lingkungan militer, akuntabilitas internal memainkan peran penting hubungan antara atasan dan bawahan. Karena bawahan mempunyai power distance yang tinggi dengan atasannya. Kultur militer yang penuh hierarkhi ini diduga 
memberikan keunikan karakteristik tersendiri dibandingkan dengan instansi sektor publik yang lain. Oleh sabab itu, penelitian di sektor militer mutlak diperlukan. Penelitian militer terdahulu di luar negeri lebih banyak membahas politik dan sistem pertahanan militer.

OCB adalah tindakan ekstra yang melebihi deskripsi peran karyawan. Tidakan ekstra yang dilakukan karyawan contohnya menolong rekan, berpartisipasi aktif, menggunakan waktu kerja secara efektif, tidak membolos ketika hari kerja dan lain sebagainya. Dengan kata lain karyawan tidak hanya mengerjakan tugas pokoknya saja tetapi mengerjakan tugas ekstra yang membuat nilai lebih untuk keefektifan organisasi.

Beberapa penelitian menunjukkan bahwa OCB berpengaruh positif terhadap kinerja karyawan dan efektifitas organisasi. Tetapi dalam konteks sektor publik, khususnya sektor militer, kinerja dan efektivitas mereka masih di pertanyakan. Kinerja sektor publik banyak mempertimbangkan kinerja formal (in role) dan mengabaikan dimensi perilaku kerja seperti OCB (extra-role), motif altrusitik, komitmen (Camilleri dan Heidjen, 2007).Sehingga penting untuk mengetahui dan memahami identifikasi pegawaiyang berpengaruh terhadap OCB.

Penelitian yang dilakukan di sektor militer masih sangat jarang. Padahal, dari segi urgensi keuangan, porsi anggaran belanja negara yang disisihkan dari keseluruhan APBN Indonesia di bidang pertahanan tidaklah sedikit. Dari data pokok APBN yang dikeluarkan oleh Kementrian Keuangan tahun 2006-2012, setiap tahunnya, 5-7\% dari total pembelanjaan APBN dialokasikan ke sektor pertahanan. Pada tahun 2006, pertahanan mengambil porsi 5,9\% total APBN. Angka ini merangkak naik menjadi 6,7 \% di tahun 2012 dan di tahun 2013 (RAPBN). Lonjakan anggaran di bidang pertahanan telah mencapai 3 kali lipat dari tahun 2007 hingga tahun 2013, yaitu dari 30,7 triliun rupiah menjadi 81,8 triliun rupiah. Belanja pertahanan ditujukan untuk investasi keamanan dan kedaulatan Indonesia, sehingga iklim mampu membantu tugas TNI untuk menegakkan kedaulatan Indonesia yang mendukung pembangunan.Ditengah urgensi akan akuntabilitas dan pengukuran kinerja, sangat ironis bila riset mengenai akuntabilitas dan kinerja di sektor militer di Indonesia tidak tersentuh. TNI membutuhkan riset untuk dapat menyusun strategi penguatan pertahanan baik dari sisi hardware, maupun software. Aspek manusia merupakan aspek software yang perlu diperhatikan.

Jarangnya penelitian di sektor militer mungkin akibat dari birokrasi yang sulit ditembus oleh para peneliti dan masyarakat umum. Oleh sebab itu, penelitian ini mencoba menutup gap tersebut dengan mamulai penelitian yang bertemakan akuntansi manajemen sektor militer, khususnya terkait akuntabilitas, komitmen organisasi, dan organization citizenship behaviour.Tujuan dari penelitian ini yaitu mengetahui ada tidaknya akuntabilitas dan organization citizenship behavior di Institusi militer di Yogyakarta, Indonesia. Berdasarkan latar belakang diatas maka pertanyaan dalam penelitian ini adalah: (1) Apakah komitmen organisasi berpengaruh terhadap OCB?; (2) Apakah akuntabilitas memediasi hubuangan komitmen organisasi dan OCB?

\section{KAJIAN TEORI}

Organizational Citizenship Behavior (OCB). Definisi OCB adalah an interest in work that is discretionary, not directly or explicitly recognized by the formal reward system, and that in the aggregate promotes the effective functioning of the organization" (Organ 1988) dalam Rayner, et al (2012). OCB terdiri dari lima dimensi yaitu altruism, conscientiousness, courtesy, sportmanship, dan civic virtue. Altruisme berkaitan dengan 
sikap membantu orang lain, conscientiousnes tentang prasyarat yang melebihi kinerja minimum seperti datang lebih awal dari jam kerja, courtesy tentang perilaku sopan dan taat peraturan sehingga mengurangi konflik interpersonal, sportmanship tentang sikap toleran terhadap kondisi yang tidak menguntungkan dan tidak suka mengeluh atas kondisi tersebut, dan civic virtue tentang kepedulian terhadap kelangsungan hidup organisasi.

William dan Anderson (1991) membedakan kategori OCB yaitu perilaku yang bermanfaat untuk organisasi dan perilaku yang bermanfaat secara langsung bagi individu dan secara tidak langsung juga bermanfaat untuk organisasi. Camilleri dan Heidjen (2007) menjelaskan bahwakomponenutama dari kinerja karyawan untuk orientasi sistem organisasi terdiri dari OCB, penekanan identifikasi karyawan, loyalitas, komitmen dan memiliki reward individu yang terhubung dengan kinerja organisasi. OCB sangat penting dalam mendukung kinerja organisasi (Podsakoff et al., 2009).

Komitmen Organisasi. Konsep komitmen organisasional didasarkan pada premis bahwa individu membentuk suatu keterikatan (attachment) terhadap organisasi (Setiawan dan Gozali, 2006). Komitmen organisasi menciptakan ikatan batin antara pekerja dengan organisasi yang mendukung pencapaian kinerja yang lebih baik. Menurut Meyer dan Allan (1995) komitmen organisasi tersusun atas: (1) Komponen affective yaitu keterikatan emosional terhadap organisasi dimana pegawai mengidentifikasikan diri dengan organisasi dan menikmati keanggotaan dalam organisasi; (2) Continuance commitment merupakan kecenderungan untuk tetap bekerja di organisasi karena biaya pengunduran diri dianggap terlalu besar. Biaya ini dapat berupa biaya langsung, tidak langsung, maupun biaya atas kesempatan yang hilang / opportunity cost; (3) Normative commitment merupakan suatu tanggung jawab untuk tetap berada dalam organisasi. Tanggung jawab ini dapat berupa beban moral yang menyebabkan pekerja merasa harus berada di organisasi tersebut.

Akuntabilitas. Akuntabilitas adalah konsep yang sering digunakan tetapi sukar dipahami dan sampai sekarang belum ada definisi akuntabilitas yang disepakati oleh para ahli. Akuntabilitas di sektor publik memiliki makna yang elusif atau sukar dimengerti sehingga dapat diartikan dari berbagai perspektif (Sinclair, 1995). Bovens (2007) mendefinisikan akuntabilitas sebagai hubungan antara aktor dengan forum, dimana aktor memiliki kewajiban untuk menjelaskan dan menjustifikasi apa yang sudah dilakukannya, sedangkan forum dapat mengajukan pertanyaan dan pertimbangan, kemudian aktor bisa jadi menemui konsekuensi.

Akuntabilitas berasal dari bahasa Prancis kuno yaitu comper atau conter yang berarti to account atau to enumerate (Cut dan Muray, 2000). Secara eksplisit, arti to account sendiri adalah untuk menghitung. Bovens (2007) menegaskan secara etymological dan akar historis bahwa akuntabilitas datang dari akuntansi. Menurut kamus oxford, akuntabilitas berarti tanggung jawab seseorang untuk memberikan perhitungan dan kejelasan atas sesuatu. Makna akuntabilitas kemudian diperluas dengan berbagai penelitian yang mengembangkan akuntabilitas dalam berbagai konteks. Akbar (2012) makna akuntabilitas tergantung pada konteks yang melekat pada kata akuntabilitas. Akuntabilitas yang akan diambil

Sinclair (1995) menyebutkan lima bentuk akuntabilitas, yaitu akuntabilitas politik, akuntabilitas publik, akuntabilitas manajerial, akuntabilitas profesional, dan akuntabilitas personal. Menurut LAN (2010) implementasi akuntabilitas di pemerintah indonesia harus mencakup akuntabilitas keuangan, akuntabilitas administrasi, akuntabilitas kebijakan publik, akuntabilitas politik dan akuntabilitas hukum. Namun,Penelitian ini menggunakan 
2 jenis/tipe akuntabilitas yaitu akuntabilitas internal dan akuntabilitas eksternal yang dipakai dalam penelitian Akbar (2012).

Dalam konteks TNI, Akuntabilitas internal mencangkup kewajiban langsung anggota untuk melaporkan pekerjaan yang telah diperintahkan kepada atasan langsung. Pelaporan mencangkup keberhasilan pelaksanaan tugas dan kendala yang dihadapi. Dalam dunia militer, kecepatan dalam melapor sangat ditekankan. Proses monitoring tugas bersifat aktual dan sepanjang pelaksanaan akan ada pelaporan, baik tugas tersebut berhasil maupun gagal. Akuntabilitas internal berhubungan langsung dengan sistem kerja sehari-hari organisasi.

Sebaliknya, akuntabilitas eksternal mencangkup kewajiban untuk melapor ke entitas lain di luar organisasi. Dalam era reformasi birokrasi, tentu saja akuntabilitas eksternal akan terus dinaikkan. Media dan publik saat ini sensitif terhadap apa yang terjadi di instansi pemerintah, termasuk instansi militer. Untuk sektor publik (pemerintahan) dengan tuntutan reputasi publik yang tinggi maka akuntabilitas yang sesuai adalah akuntabilitas internal dan eksternal (Riketa dan Landerer 2002).

Pengembangan Hipotesis. Komitmen merupakan variabel penting untuk kualitas dan kinerja (fry, et al 2005). Menurut Camillery dan Heidjen (2007) komitmen organisasi merupakan faktor esensial dalam pengembangan sumberdaya manusia (human capital). Selanjutnya Camileri dan Heidjen (2007) menyatakan bahwa kekurangan atau kesenjangan komitmen organisasi akan menyebabkan tingginya turnover, menambah biaya untuk perekrutan, seleksi, dan pelatihan. Selain itu kesenjangan komitmen organisasi akan menyebabkan karyawan mengambil aktivitas ekstra-contractual. Ketika komitmen yang dimiliki pegawai itu rendah maka mereka akan mengejar keuntungan pribadi dan mengabaikan akuntabilitas, sebaliknya ketika komitmen pegawai itu tinggi maka dia akan berperilaku sesuai norma-norma yang ditentukan yaitu menjunjung tinggi akuntabilitas.

TNI dihadapkan dengan tugas yang berat dan rawan keselamatan. Tak jarang anggota TNI akan mengalami mutasi kerja di berbagai kota di seluruh Indonesia. Hal ini sudah merupakan bagian dari sumpah prajurit dan sumpah perwira untuk patuh terhadap perintah untuk ditempatkan dimana saja, termasuk di daerah konflik. Doktrin TNI Tri Dharma Eka Karma mewajibkan seluruh anggota TNI untuk patuh terhadap perintah sepanjang masih dalam rangka menjaga pertahanan negara. Untuk dapat mewujudkan akuntabilitas pekerjaan yang berat tersebut, anggota TNI perlu memiliki komitmen yang tinggi terhadap organisasinya. Komitmen anggota TNI terhadap organisasi merupakan kriteria penting yang diujikan dalam penyeleksian anggota TNI yang baru maupun penyeleksian kenaikan pangkat TNI.

H1: Komitmen organisasi akan berpengaruh terhadap akuntabilitas anggota TNI.

Akuntabilitas merupakan salah satu elemen dasar organisasi, namun teori dan penelitian dibidang ini terkait dengan perilaku dalam organisasi sangat sedikit. March dan Olsen (1989) dalam Moynihan dan pandey (2007) mengamati bahwa harapan, preferensi, pengalaman, dan interpretasi dari tindakan orang lain semua dibangun dalam institusi. Orang membangun keyakinan dan perilaku berdasarkan apa yang dilihat dan tepat dalam lingkungan mereka dan norma-norma perilaku orang-orang di sekitar mereka. Akuntabilitas melibatkan harapan atau asumsi bahwa individu akan berperilaku dengan cara tertentu (Hall, et al 2004). Jelas bahwa perilaku karyawan mempunyai hubungan dengan akuntabilitas. Kepercayaan dan akuntabilitas tertanam dalam konteks sosial yang 
berhubungan dengan variabel sosial-psikologis dalam konteks organisasi baik formal maupun informal (Ammeter et al 2004 dalam Hall, et al 2004).

Menurut Budiyanto (2013) untuk menciptakan efektifitas organisasi yang berdampak pada peningkatan produktifitas, perlu menciptakan suasana kerja yang memberi peluang munculnya perilaku OCB dikalangan pegawai. Di instansi militer, tuntutan akuntabilitas internal sangat tinggi. Akuntabilitas internal ini diduga dapat menjadi pemicu anggota berperilaku OCB. Dari sisi akuntabilitas eksternal, dunia militer tidak lagi ekslusif dan tertutup seperti pada era orde baru. Publik menyaksikan dan turut mengawasi kinerja TNI dalam menjalankan tugasnya. Oleh sebab itu, kesadaran anggota TNI akan akuntabilitas eksternal yang harus dipenuhi akan mampu meningkatkan semangat untuk berperilaku OCB.

H2: Akuntabilitas akan berpengaruh terhadap organizational citizenship behavior

Menurut Budiyanto (2013) untuk menciptakan efektifitas organisasi yang berdampak pada peningkatan produktifitas, perlu menciptakan suasana kerja yang memberi peluang munculnya perilaku OCB dikalangan pegawai.Riketta dan Landerrer (2002) menemukan bahwa komitmen organisasi berpengaruh positif terhadap perilaku kerja dalam hal ini OCB. Individu yang mempunyai komitmen organisasi afektif yang tinggi akan memiliki niat untuk membalas (reciprocate) untuk organisasi melalui melibatkan diri dalam OCB (Cropanzano et al., 2003).

Lingkunggan kerja yang menyuburkan komitmen organisasi akan berkontribusi dengan peningkatan kualitas kerja. Caraanggota TNI melihat lingkungan kerja dapat mempengaruhi kinerja dan lingkungan kerja juga memainkan peran kunci dalam mengembangkan sikap dan perilaku pekerjaan. Menyadari akan pentingnya komitmen organisasi, pemerintah di tahun 2011 mulai memberikan remunerasi yang berupa tunjangan jabatan untuk meningkatkan kesejahteraan anggota TNI, sehingga diharapkan komitmen organisasi semakin tinggi.

H3 : komitmen organisasi akan berpengaruh terhadap organizational citizenship behavior

H3

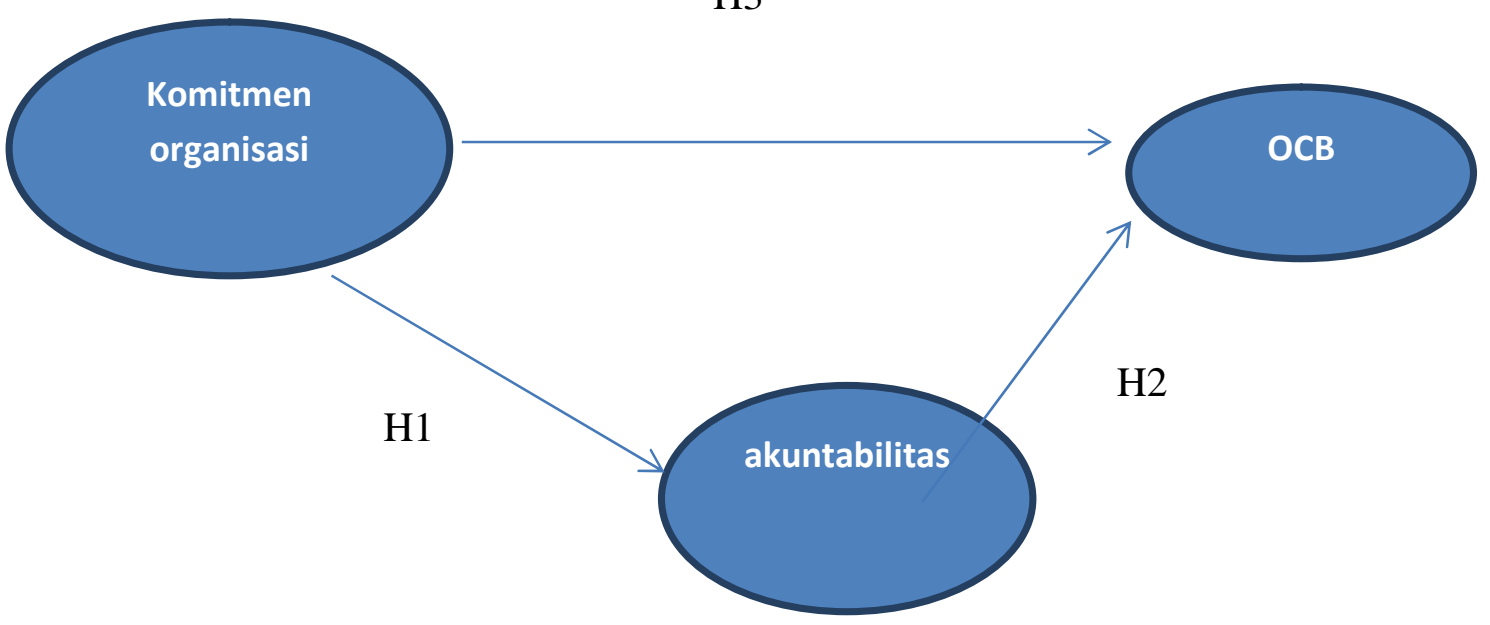

Gambar 1. Model Penelitian 


\section{METODE}

Populasi Sampel dan Tehnik Pengambilan Sampel. Populasi dalam penelitian ini adalah seluruh pegawai angkatan udara propinsi Yogyakarta. Peneliti mempertimbangkan kesamaan kultur organisasi militer di Indonesia yaitu TNI angkatan darat, angkatan udara, dan angkatan laut. Kesamaan kultur ini karena para perwira pemimpin militer yang membangun budaya di 3 matra dididik secara bersama-sama di Akademi Militer di Magelang. Setelah melewati pendidikan bersama selama kurang lebih 3 bulan di Akademi Militer, sebelum kemudian para taruna dididik di masing-masing akademi (Akademi Militer untuk taruna angkatan darat, Akademi Angkatan Udara untuk taruna angkatan udara, dan Akademi Angkatan laut untuk taruna angkatan laut. Pendidikan dasar inilah yang dianggap mampu mencuci otak dan menanamkan pola pikir kepemimpinan nasionalisme para calon pemimpin militer.

Angkatan udara di Yogyakarta memiliki aktivitas yang tergolong padat. Pusat pendidikan taruna AAU selama empat tahun dan pendidikan penerbangan calon pilot militer terdapat di Yogyakarta. Rumah sakit pusat angkatan udara pun terletak di Yogyakarta. Budaya yang ada di landasan udara militer Yogyakarta kompleks dan dinamis. Oleh sebab itu, pengambilan sampel di angkatan udara Yogyakarta tepat untuk penelitian ini. Teknik pengambilan sampel menggunakan metode non probabilistic sampling yaitu setiap elemen dalam populasi tidak memiliki probabilitas yang sama untuk menjadi sampel (Sekaran, 2003).

Data dan Sumber Data. Karena data yang diperlukan berupa opini individu maka teknik pengumpulan data dalam penelitian ini berupa survey. Survey merupakan proses pengukuran yang digunakan untuk mengumpulkan informasi dalam sebuah wawancara yang terstruktur dengan baik dengan atau tanpa seorang pewawancara (Cooper dan Schindler, 2011:242). Alat pengumpulan data menggunakan survey kuisioner yang berisi pertanyaan untuk responden. Kuisioner diantar langsung ke kantor angkatan udara Yogyakarta.

Definisi Operasional Variabel dan Pengukuran Variabel. Komitmen Organisasi. Komitmen organisasi diukur dari 1 faktor/ dimensi yaitu afektif dengan 4 item versi Meyer dan Allen (1997) konsisten dengan penelitian Fry,et al (2011), Riketta dan Landerer (2002),

Akuntabilitas. Akuntabilitas eksternal adalah akuntabilitas dari entitas pemerintah lokal untuk pemangku kepentingan seperti pemerintah pusat, DPRD, dan masyarakat (Akbar,2012). Akuntabilitas eksternal diukur dengan 5 item konsisten dengan Riketta dan landerer (2002). Akuntabilitas internal terkait hubungan antara atasan dan bawahan dalam organisasi (Stewart dan Walsh, 1994 dalam Akbar, 2012). akuntabilitas internal diukur dengan2 item sama dengan Akbar (2012).

Perilaku Kerja (Organization Citizenship Behaviour). Organization Citizenship Behaviour adalah perilaku karyawan yang melebihi peran yang diwajibkan, yang secara tidak langsung diakui secara eksplisit oleh sistem reward formal (Organ,1988 dalam Bolino, et al 2002). OCB diukur dengan 4 item dari dimensi arah langsung ke organisasi dan 4 dimensi arah langsung ke individu (William dan Anderson, 1991). Pengukuran ini konsisten dengan Chen dan Yang (2012), Rayner et al (2012). 


\section{HASIL DAN PEMBAHASAN}

Kuisioner yang disebar dalam penelitian ini berjumlah 100 kuisioner dan kembali $100 \%$. Ada 6 kuisioner yang datanya tidak lengkap, sehingga kuisioner yang bisa diolah berjumlah 96. Tingkat respon rate 100\% mungkin dikarenakan belum ada penelitian terdahulu di kesatuan angkatan udara Yogyakarta, sehingga membuat pegawai antusias untuk mengisi kuisioner. Demografi responden bisa dilihat di Tabel 1.

Tabel 1. demografi responden

\begin{tabular}{lll}
\hline Profil & keterangan & jumlah \\
\hline Usia & Dibawah 25 tahun & 12 \\
& 26-30 tahun & 23 \\
& 31-35 tahun & 15 \\
& 36-40 tahun & 17 \\
& $41-45$ tahun & 11 \\
& 46-50 tahun & 14 \\
Lama bekerja & 51 tahun keatas & 2 \\
& Dibawah 5 tahun & 15 \\
& 6-10 tahun & 22 \\
& 11-15 tahun & 15 \\
Pendidikan & 16-20 tahun & 15 \\
& Diatas 20 tahun & 27 \\
& Sma & 90 \\
& Diploma & 3 \\
& S1 & 0 \\
& S2 & 1 \\
\hline
\end{tabular}

Uji Validitas dan Reliabilitas Instrumen Penelitian. Uji validitas merupakan tingkat dimana sebuah pengujian mengukur apa yang benar-benar ingin diukur (Cooper dan Schindler, 2011:280). Uji validitas dapat dilihat dari skor loading indikator konstruk bernilai diatas 0,5 . Ada beberapa indikator yang nilainya dibawah 0,5 yaitu indikator konstruk OC4 dengan nilai skor loading 0,195, indikator konstruk AC 4 dan AC7 masing masing nilai skor loadingnya 0,319 dan 0,458, dan indikator konstruk OCB2 dengan skor loading 0,280 , sehingga indikator-indikator tersebut dikeluarkan/dihapus. Indikatorindikator tersebut memiliki skor loading rendah karena pertanyaan yang diajukan ambigu dan tidak sesuai dengan konteks organisasi militer.

Dari wawancara singkat dengan responden terkait pertanyaan-pertanyaan yang memiliki skor loading rendah, dapat disimpulkan bahwa responden tidak memahami konteks pertanyaan karena tidak sesuai dalam konteks sehari-hari dalam pekerjaan. Dalam hal ini, bias kompleksitas item dan ambiguitas item mungkin sekali terjadi akibat kata-kata yang tidak dikenal (Peterson, 2000) dan konteks pertanyaan yang tidak dikenal dan dialami di keseharian pekerjaannya. Oleh sebab itu, untuk meminimalisir bias kompleksitas item dan ambiguitas item, pertanyaan tersebut dihapus dari analisa statistik.

Hasil uji validitas setelah indikator konstruk yang nilainya dibawah 0,5 dikeluarkan dapat dilihat pada Tabel 2. Uji validitas terdiri dari dua yaitu uji validitas konvergen dan uji validitas diskriminan. Uji validitas konvergen dilihat dari skor AVE dan Communality yang masing-masing memiliki nilai 0,5. Skor AVE yang memenuhi batas 0.5 menunjukkan bahwa konsep-konsep secara teori berkorelasi dengan kenyataan (Jogiyanto, 
2011). Uji validitas diskriminan dilihat dari skor loading diatas 0,5 dapat dilihat pada Tabel 2.

Tabel 2. Iterasi Algoritma

\begin{tabular}{lllllll}
\hline & AVE & $\begin{array}{l}\text { Composite } \\
\text { reliability }\end{array}$ & R Square & $\begin{array}{l}\text { Cronbachs } \\
\text { Alpha }\end{array}$ & Communality & Redudancy \\
\hline AC & 0,5188 & 0,8429 & 0,1762 & 0,7659 & 0,5188 & 0,0897 \\
OC & 0,6302 & 0,8363 & 0,0000 & 0,7071 & 0,0000 & 0,0000 \\
OCB & 0,5066 & 0,8769 & 0,4392 & 0,8354 & 0,5066 & 0,1241 \\
\hline
\end{tabular}

Uji validitas diskriminan menunjukkan bahwa antar intrumen pengukur konstruk tidak berkorelasi dengan tinggi (Jogiyanto, 2011). Uji reliabilitas berkaitan dengan akurasi dan presisi dari sebuah prosedur pengukuran (Cooper dan Schindler, 2011:283). Suatu kuisioner dikatakan reliable jika jawaban seseorang terhadap pernyataan adalah kosisten, atau stabil dari waktu ke waktu dan nilai cronbach alpha> 0,60 (Hartono, 2011). Seluruh konstruk dalam penelitian ini telah memenuhi uji reliabilitas dilihat dari nilai cronbach alpha> 0,60 dan nilai Composite reliability> 0,7.

Evaluasi model struktural dinilai berdasarkan $R$ Square (Tabel 2) yang menunjukan nilai 0,4392 untuk konstruk OCB. Artinya model yang diajukan dapat menjelaskan konstruk OCB sebesar 43,92\% sisanya dijelaskan oleh faktor lain diluar model penelitian.

Uji Hipotesis. Untuk melihat signifikasi uji hipotesis yang diajukan dengan cara membandingkan nilai t-statistik dengan nilai t-tabel. Jika nilai t-statistik lebih tinggi dari nilai t-tabel, maka hipotesis terdukung. Sebaliknya, apabila t-statistik lebih rendah, maka tidak terdukung. Nilai t-tabel 1,645 (1-tailed) dan 1,960 (2-tailed) dengan tingkat keyakinan $95 \%$.

Tabel 5. Koefisien Jalur

\begin{tabular}{llllll}
\hline & $\begin{array}{l}\text { Original } \\
\text { Sample (O) }\end{array}$ & $\begin{array}{l}\text { Sample } \\
\text { Mean (M) }\end{array}$ & $\begin{array}{l}\text { Standard } \\
\text { Deviation } \\
\text { (STDEV) }\end{array}$ & $\begin{array}{l}\text { Standard } \\
\text { Error } \\
\text { (STERR) }\end{array}$ & $\begin{array}{l}\text { T Statitics } \\
\text { (O/STERR) }\end{array}$ \\
\hline AC-> OCB & 0,3549 & 0,3709 & 0,1509 & 0,1509 & 2,3516 \\
OC-> AC & 0,4199 & 0,4290 & 0,0953 & 0,0953 & 4,4034 \\
OC-> OCB & 0.4305 & 0,4193 & 0,1147 & 0,1147 & 3,7544 \\
\hline
\end{tabular}

Hasil pengujian hipotesis dapat dilihat Tabel 5. Dari Tabel 5 didapatkan bahwa semua hipotesis terdukung dengan nilai t-statistik untuk hipotesis pertama 4,4034 lebih tinggi dari t-tabel 1,1960, hipotesis kedua mempunyai nilai t-statistik 2,3516 dan hipotesis ketiga memiliki nilai t-statistik 3,7544. Hasil penelitian ini mendukung penelitian Riketta dan landerrer (2002) yang menemukan bahwa komitmen organisasi berpengaruh terhadap OCB. Penelitian ini memperkaya penelittian terdahulu dengan memberikan dukungan terhadap posisi akuntabilitas sebagai variabel intervening yang memediasi hubungan antara komitmen organisasi dengan OCB.

\section{PENUTUP}

Simpulan. Hasil pengujian hipotesis dapat dilihat dari Tabel 5. Dari Tabel 5 didapatkan bahwa semua hipotesis terdukung dengan nilai t-statistik untuk hipotesis pertama 4,4034 
lebih tinggi dari t-tabel 1,1960, hipotesis kedua mempunyai nilai t-statistik 2,3516 dan hipotesis ketiga memiliki nilai t-statistik 3,7544. Hasil penelitian ini mendukung penelitian Riketta dan landerrer (2002), Feldman dan Ng (2011) yang menemukan bahwa komitmen organisasi berpengaruh terhadap OCB. Memperkaya penelitian sebelumnya, penelitian ini membuktikan bahwa akuntabilitas terbukti memediasi hubungan antara komitmen organisasi dengan OCB.

Hasil penelitian ini menunjukkan bahwa di sektor militer pun, komitmen organisasi dan akuntabilitas memegang peranan yang sangat penting untuk meningkatkan perilaku kerja yang baik, atau dalam hal ini disebut organization citizenship behaviour. Tak heran jika dalam tes wawancara penerimaan calon tentara, baik dari jalur tamtama, bintara, perwira karir, maupun perwira taruna akademi, komitmen terhadap organisasi TNI merupakan kriteria yang sangat penting. Dasar komitmen pribadi anggota dipadukan dengan akuntabilitas yang tercipta selama menjalankan pekerjaan mendukung terciptanya organization citizenship behaviour.

Dari pengalaman kerja responden yang cukup lama dan respons rate yang cukup tinggi, dapat disinyalir bahwa tingkat kebersamaan dan kebersatuan antar anggota cukup tinggi. Artinya, tindakan rekan untuk saling membantu besar. Ketika kuesioner disebar, begitu satu orang bersedia mengisi, anggota lain bergegas untuk mengambil dan mengisi kuesioner dengan segera. Namun, untuk meningkatkan validitas eksternal penelitian, sampel yang disebar perlu diperluas, mencangkup TNI AD dan TNI AL. Perluasan cakupan diharapkan mampu meningkatkan tingkat generalisasi hasil riset.

Saran. Riset ini dapat dikembangkan dengan memasukkan variabel tambahan yaitu tipe kepemimpinan dari pemimpin militer mengingat garis komando di dunia militer begitu tegas. Gadot (2007) menemukan efek tipe kepemimpinan pada kinerja karyawan.Namun, belum pernah diuji apakah pengaruh tipe kepemimpinan terhadap OCB di lingkungan yang bergaris komando tegas akan sama dengan penelitian sebelumnya. Penelitian ini diharapkan menjadi awal dari penelitian-penelitian lanjutan di bidang akuntansi manajemen di sektor militer di Indonesia.

\section{DAFTAR RUJUKAN}

Akbar, R., (2011) "Performance Measurement and Accountability in Indonesian Local Government". Desertasi Curtin University.

Ariani, D.W. (2011) "Hubungan antara perilaku kewarganegaraan organisasional dan kinerja tugas". Jurnal manajemen teori dan terapan, tahun 4 No1.

Bolino, M.C. Turnley, W.H,. dan Bloodgood, J.M. (2002) citizenship behavior and the creation of social capital in organizations. Academy of management review, 27, 505522.

Bovens, M. (2007) new forms of accountability and EU-governance. Comparative europeanpolitics. 5, 104-120.

Budiyanto. (2013) pengembangan organisasi sektor publik (pemerintah) dengan pendekatan organizational citizenship behavior (OCB). Orasi ilmiah dies natalis ke 41 STIESA.

Camilleri, E. dan Heijden, B.V. (2007) "Organizational comitment, public service motivation and performance within the public sector". Public performance and managerial review Vol 31 No 2. 
Chen, C.Y,. dan Yang, C.F. (2012) "The impact of spiritual leadership on organizational citizenship behavior: A multi sample analysis". J bus ethics, 105: 107-114.

Cooper, D. R. dan Schindler, P. S. (2011) Business research methods. Edisi 11. New York. NY: McGraw-Hill.

Cutt, J. dan Murray, V. (2000) Accountability and Effectiveness Evaluation in Non-Profit Organizations. London: Routledge.

Fry, L.W,. Vitucci, S. dan Cedillo, M. (2005) Spiritual leadership and army transformation: theory measurement, and establishing a baseline. The leadership quartely 16:835-862

Gadot, Eran Vigoda. (2005) Leadership Style, Organizational Politics, and Employees' Performance. Personnel Review, Vol 36 No.5.

Hall, A.T., Blass, F.R., Ferris, G.R., dan Massengale, R. (2004) Leader reputation and accountability in organizations: implications for disfunctional leader behavior. The leadership quartely, 15:515-536.

Hartono, Jogiyanto. (2011) Pedoman Survei Kuesioner. BPFE, Universitas Gadjah Mada, Yogyakarta.

Hartono, Jogiyanto. (2011) Konsep dan Aplikasi Structural Equation Model Berbasis Varian Dalam Penelitian Bisnis. UPP STIM YKPN.

Lembaga Administrasi Negara,. (2010) Naskah akademik sistem akuntabilitas nasional.

Ng, T.W.H dan Feldman, D.C. (2011) "Affective Organizational Commitment and Citizenship Behaviour: Linear and Non-Linear Moderating Effects of Organizational Tenure". Journal of Vocational Behaviour. 528-537

Moynihan, D.P. dan Pandey, S.K. (2007) "The role of organizations in fostering public service motivation'. Public administration review. Vol 67 No.1.

Peterson, R.A. (2000) Constructing Effective Questionnaires. Thousand Oaks, CA: Sage

Podsakoff, N.P, Blume, B.D, Whiting, S.W, dan Podsakoff, P.M. (2009) "Individual and Organizatio Level Consequencesof Organizational Citizenship Behaviours: A Meta Analysis". Journal of Applied Psychology, 94, 122-141.

Rayner, J. Lawton, A. dan Williams, H. M. (2012) "Organizational citizenship behavior and public service ethos: whither the organization?". J Bus Ethics 106, 117-130.

Riketta, M. dan Landerer, A. (2002) Organizational commitment, accountability and work behavior: a correlation study. Social behavior and personality 30 (7) 653-660.

Rus, D., Knippenberg, D., Wisse, B. (2011) Leader power and self serving behavior: the moderating role of accountability. The leadership quartely 23: 13-26.

Sinclair, Amanda. (1995) The Chameleon of Accountability: Forms and Discourses. Accounting, Organization, and Society, vol. 20 no.2/3. Pp 219-237

Sekaran, U. (2003) Research method for business: A skill building approach, 4th edition. John Wiley \& Sons. New York

Setiawan, I,A.dan Gozali (2006) Akuntansi Keperilakuan: Konsep dan Kajian Empiris Perilaku Akuntan. Semarang: Universitas Diponegoro.

Williams, L.J dan Anderson. (1991) "Job Satisfaction and Organizational Commitment as Predictors of Organizational Citizenship and in Role-Behaviors". Journal of Management 17:601. 


\section{Lampiran}

Tabel 1 demografi responden

\begin{tabular}{|l|l|l|}
\hline Profil & keterangan & jumlah \\
\hline Usia & Dibawah 25 tahun & 12 \\
\cline { 2 - 3 } & $26-30$ tahun & 23 \\
\cline { 2 - 3 } & $31-35$ tahun & 15 \\
\cline { 2 - 3 } & $36-40$ tahun & 17 \\
\cline { 2 - 3 } & $41-45$ tahun & 11 \\
\cline { 2 - 3 } & $46-50$ tahun & 14 \\
\cline { 2 - 3 } & 51 tahun keatas & 2 \\
\hline Lama bekerja & Dibawah 5 tahun & 15 \\
\cline { 2 - 3 } & 6-10 tahun & 22 \\
\cline { 2 - 3 } & $11-15$ tahun & 15 \\
\cline { 2 - 3 } & $16-20$ tahun & 15 \\
\cline { 2 - 3 } & Diatas 20 tahun & 27 \\
\hline Pendidikan & Sma & 90 \\
\cline { 2 - 3 } & Diploma & 3 \\
\cline { 2 - 3 } & S1 & 0 \\
\cline { 2 - 3 } & S2 & 1 \\
\hline
\end{tabular}

Tabel 2 iterasi algoritma

\begin{tabular}{|l|l|l|l|l|l|l|}
\hline & AVE & $\begin{array}{l}\text { Composite } \\
\text { reliability }\end{array}$ & R Square & $\begin{array}{l}\text { Cronbachs } \\
\text { Alpha }\end{array}$ & Communality & Redudancy \\
\hline AC & 0,5188 & 0,8429 & 0,1762 & 0,7659 & 0,5188 & 0,0897 \\
\hline OC & 0,6302 & 0,8363 & 0,0000 & 0,7071 & 0,0000 & 0,0000 \\
\hline OCB & 0,5066 & 0,8769 & 0,4392 & 0,8354 & 0,5066 & 0,1241 \\
\hline
\end{tabular}

Tabel 3 korelasi variabel laten

\begin{tabular}{|l|l|l|l|}
\hline & AC & OC & OCB \\
\hline AC & 1,0000 & & \\
\hline OC & 0,4199 & 1,0000 & \\
\hline OCB & 0,5357 & 0,5792 & 1,0000 \\
\hline
\end{tabular}

Tabel 4 Cross loading

\begin{tabular}{|l|l|l|l|}
\hline & AC & OC & OCB \\
\hline AC1 & $\mathbf{0 , 6 7 4 3}$ & 0,3167 & 0,3472 \\
\hline AC2 & $\mathbf{0 , 7 9 7 8}$ & 0,3762 & 0,4051 \\
\hline AC4 & $\mathbf{0 , 7 7 9 8}$ & 0,3563 & 0,4501 \\
\hline AC5 & $\mathbf{0 , 6 6 5 8}$ & 0,3156 & 0,4062 \\
\hline AC6 & $\mathbf{0 , 6 9 2 6}$ & 0,3235 & 0,3573 \\
\hline OC1 & 0,3694 & $\mathbf{0 , 8 1 6 4}$ & 0,4860 \\
\hline OC2 & 0,3077 & $\mathbf{0 , 7 7 7 1}$ & 0,4721 \\
\hline OC3 & 0,3197 & $\mathbf{0 , 7 8 7 6}$ & 0,4182 \\
\hline OCB1 & 0,2750 & 0,4381 & $\mathbf{0 , 7 5 2 2}$ \\
\hline
\end{tabular}




\begin{tabular}{|l|l|l|l|}
\hline OCB3 & 0,5447 & 0,3759 & $\mathbf{0 , 7 4 7 0}$ \\
\hline OCB4 & 0,4653 & 0,2534 & $\mathbf{0 , 5 5 2 9}$ \\
\hline OCB5 & 0,2980 & 0,4068 & $\mathbf{0 , 6 9 6 9}$ \\
\hline OCB6 & 0,4103 & 0,3968 & $\mathbf{0 , 7 7 6 5}$ \\
\hline OCB7 & 0,3568 & 0,5595 & $\mathbf{0 , 7 0 1 6}$ \\
\hline OCB8 & 0,2803 & 0,4166 & $\mathbf{0 , 7 3 2 6}$ \\
\hline
\end{tabular}

Tabel 5 koefisien jalur

\begin{tabular}{|l|l|l|l|l|l|}
\hline & $\begin{array}{l}\text { Original } \\
\text { Sample (O) }\end{array}$ & $\begin{array}{l}\text { Sample } \\
\text { Mean (M) }\end{array}$ & $\begin{array}{l}\text { Standard } \\
\text { Deviation } \\
(\text { STDEV })\end{array}$ & $\begin{array}{l}\text { Standard } \\
\text { Error } \\
(\text { STERR })\end{array}$ & $\begin{array}{l}\text { T Statitics } \\
\text { (O/STERR) }\end{array}$ \\
\hline AC-> OCB & 0,3549 & 0,3709 & 0,1509 & 0,1509 & 2,3516 \\
\hline OC-> AC & 0,4199 & 0,4290 & 0,0953 & 0,0953 & 4,4034 \\
\hline OC-> OCB & 0.4305 & 0,4193 & 0,1147 & 0,1147 & 3,7544 \\
\hline
\end{tabular}

\section{Instrumen Penelitian}

\begin{tabular}{|c|c|}
\hline No & Pertanyaan \\
\hline & Akuntabilitas \\
\hline 1 & Saya bekerja dengan cukup terbuka terhadap publik \\
\hline 2 & $\begin{array}{l}\text { Pihak di luar organisasi saya jarang menyadari apakah saya telah bekerja dengan } \\
\text { baik atau dengan buruk }\end{array}$ \\
\hline 3 & $\begin{array}{l}\text { Jika saya bekerja dengan tidak baik, maka tindakan saya tersebut dapat } \\
\text { mempengaruhi reputasi organisasi saya di lingkungan saya }\end{array}$ \\
\hline 4 & $\begin{array}{l}\text { Saya bertanggung jawab terhadap apa yang dipikirkan orang tentang organisasi } \\
\text { saya dilingkungan saya. }\end{array}$ \\
\hline 5 & $\begin{array}{l}\text { Setiap pegawai harus menjaga pertanggungjelasan (akuntabilitas) dari hasil } \\
\text { aktivitas yang dilakukan }\end{array}$ \\
\hline 6 & Atasan saya secara periodik mereview hasil kerja saya \\
\hline \multirow[t]{2}{*}{7} & $\begin{array}{l}\text { Kecurangan insentif (penghargaan, kompensasi) telah dicegah dengan adanya } \\
\text { informasi kinerja. }\end{array}$ \\
\hline & Komitmen organisasi \\
\hline 1 & Saya merasa menjadi bagian dari organisasi tempat saya bekerja \\
\hline 2 & Saya senang hati menghabiskan sisa karir saya di organisasi ini \\
\hline 3 & Saya mempromosikan organisasi ini ke teman-teman \\
\hline \multirow[t]{2}{*}{4} & Masalah diorganisasi saya seperti masalah saya sendiri \\
\hline & Organization citizenship behavior \\
\hline 1 & $\begin{array}{l}\text { saya pernah dengan senang hati membantu teman sekerja yang membutuhkan } \\
\text { bantuan tanpa mengharapkan imbalan }\end{array}$ \\
\hline
\end{tabular}




\begin{tabular}{|c|c|}
\hline 2 & $\begin{array}{l}\text { saya bersedia untuk bekerja lembur untuk membantu rekan kerja anda } \\
\text { menyelesaikan pekerjaannya tanpa dikenakan gaji lembur }\end{array}$ \\
\hline 3 & Ada rasa puas dalam hati bila pekerjaan saya selesai tepat pada waktunya \\
\hline 4 & Setiap tugas yang diberikan akan saya selesaikan dengan penuh tanggungjawab \\
\hline 5 & $\begin{array}{l}\text { Saya berani mengambil risiko apapun untuk bertanggung jawab dan } \\
\text { melaksanakan hasil keputusan rapat bersama }\end{array}$ \\
\hline 6 & Saya terlibat dalam fungsi-fungsi organisasi \\
\hline 7 & $\begin{array}{l}\text { Saya rutin mengikuti kegiatan-kegiatan yang diadakan organisasi tempat saya } \\
\text { bekerja }\end{array}$ \\
\hline 8 & $\begin{array}{l}\text { Saya tertarik untuk mencari informasi-informasi penting yang dapat bermanfaat } \\
\text { bagi organisasi }\end{array}$ \\
\hline
\end{tabular}

